\title{
Effect of sulphur, zinc and boron on the growth and yield enhancement of sunflower (Helianthus annuus L.)
}

\section{Ravikumar*}

Department of Agronomy, Faculty of Agriculture, Annamalai University, Annamalai Nagar608002 (Tamil Nadu), India

\section{A. Karthikeyan}

Department of Agronomy, Faculty of Agriculture, Annamalai University, Annamalai Nagar608002 (Tamil Nadu), India

\section{P. Senthilvalavan}

Department of Soil Science and Agricultural Chemistry, Faculty of Agriculture, Annamalai University, Annamalai Nagar-608002 (Tamil Nadu), India

\section{R. Manivannan}

Department of Soil Science and Agricultural Chemistry, Faculty of Agriculture, Annamalai University, Annamalai Nagar-608002 (Tamil Nadu), India

*Corresponding author: Email: ravikumarchinnathambi@gmail.com

\section{How to Cite}

Ravikumar, C. et al. (2021). Effect of sulphur, zinc and boron on the growth and yield enhancement of sunflower (Helianthus annuus L.). Journal of Applied and Natural Science, 13(1): 295 - 300. https://doi.org/10.31018/jans.v13i1.2569

\begin{abstract}
Oilseed crops grown in different types of soil experience nutrient deficiency, especially sulphur, zinc and boron, which affect crop productivity. To tackle it, nutrient management practices must be streamlined to avoid improper fertilizations and deterioration of soil health. With this background, experimental trials were conducted to study the effect of sulphur, zinc and boron application on the growth, yield components and yield of hybrid sunflower at AyanAthur village, Ariyalur district (TN) during the summer seasons of 2016 and 2017. The experiments were laid out in Randomized Block Design (RBD) with three replications. The growth components of sunflower (plant height, leaf area index, dry matter production, leaf area duration (LAD) and growth analysis parameters such as crop growth rate (CGR), relative growth rate(RGR), net assimilation rate(NAR) and chlorophyll content, yield components and seed yield were significantly (level of significance $P>0.05$ ) influenced by foliar application of $0.5 \% \mathrm{Zn}$ on bud initiation stage and seed formation stage and B @ $0.3 \%$ on bud initiation stage and ray floret formation stage along with S(sulphur) @ $40 \mathrm{~kg} \mathrm{ha}^{-1}$ and RDF(recommended dose of fertilizers) as a soil application. Growth and yield parameters responded very little with the RDF alone. From both experimental results, we found that foliar application of Zn @ $0.5 \%$ and B @ $0.3 \%$ along with S @ $40 \mathrm{~kg} \mathrm{ha}^{-1}$ and RDF recorded the highest percentage of dry matter production (44.4\%), number of filled seeds $(30.1 \%)$ and yield $(32.4 \%)$ of hybrid sunflower.
\end{abstract}

Keywords: Boron, Chlorophyll content, Foliar spray, Sulphur, Sunflower, Zinc

\section{INTRODUCTION}

Sunflower (Helianthus annuus L.) is one of the most important oilseed crops grown worldwide by its highquality edible oil. Its high synthetic capacity and harvest index allows this crop to be productive in a broad range of environments (Agele, 2003). This crop occupies over 22.81 million hectares in the world, with a global production accounted to about 60.5 million tons.(FAO, 2019)n India, total sunflower seed production is about $0.24 \mathrm{mt} 2018-19$ with a sizable oil production of 0.068 $\mathrm{mt}$, whereas projected demand of $0.77 \mathrm{mt}$ and $0.40 \mathrm{mt}$ for seed production and oil yield respectively in 202425. Furthermore, the per capita edible oil consumption rise from 19.3 to $23.20 \mathrm{~kg} /$ person/annum during the corresponding period will escalate the edible oil requirement from 25.74 to $33.38 \mathrm{mt}$ in 2025 ( Vishnuvardhan et al., 2020). Nowadays, the consumption of edible oil is increasing, whereas production is declining due to the imbalanced application of nutrients in India. The increased demand for food grain production has led to intensive cultivation, which paves continuous depletion of soil micronutrient fertility. As a result, there is a steady fall in nutrient use efficiency and that is part- 
ly attributed due to the increased incidences of deficiencies of zinc and boron in many parts of the country (Singh and Goswami, 2014).

The deficiency of micronutrients during the last three decades has grown in both magnitude and extent because of increased use of high analysis fertilizers, use of high yielding crop varieties and increase in cropping intensity. Tamil Nadu ranks $4^{\text {th }}$ in $\mathrm{Zn}(58.4 \%)$ and $\mathrm{Fe}$ $(17 \%)$ deficiency and $5^{\text {th }}$ for $B(21 \%)$ deficiency in soils (GOI, 2015). Likewise, ICRISAT also reported the coexistence of sulphur (S) and Boron (B) deficiencies, where $S$ deficiency ranged from 46 to $96 \%$ and $B$ from 56 to $100 \%$ in various semi-arid tropical states of India (Rego et al., 2007 and Wani et al., 2011). Apart from the major nutrients, sulphur is increasingly being recognized as the fourth major plant nutrient after nitrogen, phosphorus and potassium (Tandon and Messick, 2002). Sulphur plays a predominant role in improving the seed quality of sunflower crop and also the use efficiency of nitrogen and phosphorus. In oilseeds, sulphur plays a vital role in the development of seed and improving quality (Naser et al., 2012).

Micronutrients are involved in the key physiological processes of photosynthesis and respiration (Marchner, 1995). Among the micronutrients, zinc is actively involved as both functional and structural components in the synthesis of several enzymes (Hemantaranjan, 1996). Its deficiency leads to many aberrations in plants' reproductive organs, leading to lower productivity (Neena and Chitrlekha, 2001). Scientific reports proved that the application of small doses of $B$ along with $S$ reduces the deficiency of $S$ and $B$ in crops precisely and helps in enhancing the use efficiency of NPK and other micronutrients (Singh et al., 2019). However the requirement of micronutrients is low. The application of these nutrients through foliar fertilization is a prominent one due to rapid translocation of these nutrients to leaf and seed is superior to soil application (Abdul Aziz et al., 2016). Foliar nutrients usually penetrate the leaf cuticle or stomata and enter the cells facilitating the easy entry of nutrients. Hence an attempt was made to study the effect of micronutrients through foliar application along with primary and secondary nutrients on the growth and yield enhancement of sunflower (Helianthus annuus L).

\section{MATERIALS AND METHODS}

The experiments on the effect of $Z n$ and $B$ as foliar application with different levels of sulphur along with recommended dose of fertilizers (RDF) on the growth and yield enhancement of sunflower were conducted at AyanAthur village, Ariyalur district, Tamilnadu, India, from February to April for two years in 2016 and 2017. The experimental site of the study is geographically located at $11^{\circ} 23^{\prime} \mathrm{N}$ latitudes, $79^{\circ} 29^{\prime} \mathrm{E}$ longitudes and an altitude of $+26.0 \mathrm{~m}$ of above mean sea level. The average rainfall of Ariyalur district is $1071.4 \mathrm{~mm}$, with the Southwest monsoon rain of $375 \mathrm{~mm}$, Northeast monsoon rain of $585 \mathrm{~mm}$, summer rain of $83 \mathrm{~mm}$ and winter rain of $29 \mathrm{~mm}$ during the agricultural year 2016-17. A composite soil sample was collected at a depth of 0 $30 \mathrm{~cm}$. It was air dried, crushed, and tested for physical and chemical properties. The soil was sandy clay loam in texture with soil reaction of $(\mathrm{pH} \mathrm{7.6),} \mathrm{electrical} \mathrm{con-}$ ductivity $0.69 \mathrm{dS} \mathrm{m}^{-1}$, organic matter $(0.72 \%)$, available nitrogen (152.7 kg ha-1), phosphorus (10.4 kg ha$\left.{ }^{1}\right)$,potassium (174.0 kg ha-1), sulphur $\left(7.2 \mathrm{mg} \mathrm{kg}^{-1}\right), \mathrm{Zn}$ $(0.72 \mathrm{mg} / \mathrm{kg})$ and available $B(0.56 \mathrm{mg} / \mathrm{kg})$.Experiments were carried out in a randomized block design with nine treatments ( $T_{1}-\mathrm{RDF}$ alone, $\mathrm{T}_{2}-\mathrm{RDF}+\mathrm{S} @ 20 \mathrm{~kg} \mathrm{ha}^{-1}$, $\mathrm{T}_{3}-\mathrm{RDF}+\mathrm{S} @ 20 \mathrm{~kg} \mathrm{ha}^{-1}+\mathrm{Zn} @ 0.25 \%$ as foliar spray, $\mathrm{T}_{4}-\mathrm{RDF}+\mathrm{S} @ 20 \mathrm{~kg} \mathrm{ha}^{-1}+\mathrm{B} @ 0.15 \%$ as foliar spray, $\mathrm{T}_{5^{-}} \mathrm{RDF}+\mathrm{S} @ 20 \mathrm{~kg} \mathrm{ha}^{-1}+\mathrm{Zn} @ 0.25 \%$ and B @ $0.15 \%$ as foliar spray, $\mathrm{T}_{6}-\mathrm{RDF}+\mathrm{S} @ 40 \mathrm{~kg} \mathrm{ha}^{-1}, \mathrm{~T}_{7^{-}}$ $\mathrm{RDF}+\mathrm{S} @ 40 \mathrm{~kg} \mathrm{ha}^{-1}+\mathrm{Zn} @ 0.5 \%$ as foliar spray, $\mathrm{T}_{8^{-}}$ RDF + S@ $40 \mathrm{~kg} \mathrm{ha}^{-1}+\mathrm{B} @ 0.3 \%$ as foliar spray, $\mathrm{T}^{-}$ $\mathrm{RDF}+\mathrm{S} @ 40 \mathrm{~kg} \mathrm{ha}^{-1}+\mathrm{Zn} @ 0.5 \%$ and B @ 0.3\% as foliar spray. and replicated thrice. Experimental plots consisted of two levels of sulphur (20 and $\left.40 \mathrm{~kg} \mathrm{ha}^{-1}\right)$ as soil application, $\mathrm{Zn}(0.25$ and $0.5 \%)$ and $\mathrm{B}(0.15$ and $0.3 \%$ ) as foliar application and control i.e., recommended $\mathrm{N}, \mathrm{P}$ and $\mathrm{K}\left(60: 90: 60 \mathrm{~kg}^{-\mathrm{ha}^{-1}}\right)$ alone as soil application.All the treatments were applied by balancing to the initial soil test values and crop requirements to justify the crop response to the supplied nutrients in both years.

\section{Crop management}

The land was thoroughly ploughed with a tractor-drawn implement with a criss-cross manner and levelled properly. The plots were prepared with the dimension of $8 \mathrm{~m} \times 5 \mathrm{~m}$ and seeds of hybrid sunflower Sunbred275 were sown with a spacing of $60 \times 30 \mathrm{~cm}$. For fertilization, the RDF treatment $100 \%$ of $P$ through DAP and $S$ through elemental sulphur, $50 \%$ of $\mathrm{N}$ through urea and $\mathrm{K}$ through MOP was applied basally as a soil application. Remaining $50 \%$ of $\mathrm{N}$ and $\mathrm{K}$ applied at the preflowering stage. Treatments possessing micro nutrients viz., Zn supplemented through zinc chloride @ 0.25 and $0.5 \%$ as a foliar application at bud initiation stage and seed formation stage and B through boric acid @ 0.15 and $0.3 \%$ as a foliar application at bud initiation stage and ray floret formation stage respectively. Tween - twenty as surfactant used @ $0.5 \mathrm{cc} / \mathrm{L}$ added to enhance the persistence capacity of spray solution on the leaf during the spray. At 4 - 5 leaf stage plants were thinned to appropriate density. Irrigation was given uniformly and regularly to all plots as per the requirement to prevent the crop from water stress at any stage. The crop biometric observations of growth attributes such as plant height, LAI (Leaf Area Index), LAD (Leaf Area 
Duration), DMP (Dry matter production) and also growth indices of CGR (Crop Growth Rate), RGR (Relative Growth Rate) and chlorophyll content were recorded during the study.

\section{Chlorophyll assay}

The total chlorophyll content of leaves was determined by using $80 \%$ acetone extraction suggested by Arnon (1949). About $250 \mathrm{mg}$ of fresh leaf material from each plot was taken and crushed thoroughly with $80 \%$ acetone. A homogeneous paste was made and filtered through Whatman No.1 filter paper, made up the volume with $80 \%$ acetone $25 \mathrm{ml}$. Since the extract is subjected to evaporation and photo-oxidation. The optical activity or density of chlorophyll 'a' and 'b' recorded at $645 \mathrm{~nm}$ and $663 \mathrm{~nm}$ wavelength respectively and chlorophyll $a$ and $b$ were calculated using the formula.

Chlorophyll $a=20.2 \times$ O.D value at $645 \mathrm{~nm} \times$ $100 / 1000 \mathrm{mg} \cdot \mathrm{g}^{-1 \mathrm{Eq} \cdot 1}$

Chlorophyll $\mathrm{b}=8.02 \times$ O.D value at $663 \mathrm{~nm} \times$ $100 / 1000$ mg.g ${ }^{-1}$.................. 2

Total chlorophyll content $=$ chlorophyll $\mathrm{a}+$ chlorophyll $\mathrm{b}$.

\section{Statistical analysis}

The experimental data were statistically analyzed, as suggested by Gomez and Gomez (1976). For significant results, the critical difference was worked out at 5 per cent level.

\section{RESULTS AND DISCUSSION}

\section{Effect of $\mathrm{S}, \mathrm{Zn}$ and $\mathrm{B}$ on the growth components of} sunflower

The observations recorded on growth components and growth analysis parameters are presented in Fig. 1 and 2 revealed that the effect of different levels of the sulphur application combines with micronutrients and had a positive influence on all growth components viz., plant height, LAI, DMP, and LAD and growth analysis viz., CGR, RGR and chlorophyll content in both the crop period. Among the different levels of sulphur, higher plant height of $172.3 \mathrm{~cm}$ and $168.4 \mathrm{~cm}$, LAl of 6.9 and 6.6, DMP of 7130.4 and $6725.0 \mathrm{~kg} \mathrm{ha}^{-1}$ and LAD of 53.5 and 51.9 days were recorded with the application of elemental sulphur @ $40 \mathrm{~kg} \mathrm{ha}^{-1}$ along with RDF (60:90:60 kg ha ${ }^{-1}$ ) and micronutrients both Zn @ 0.5\% and B@ $0.3 \%$ as foliar spray over other levels and combinations of treatments. The same trend was noticed in the growth analysis parameters such as CGR, RGR, NAR and total chlorophyll during both the crop period. This might be due to that $S$ plays a predominant role in more synthesis of amino acids increased chlorophyll content in a growing region and improving the photosynthetic activity, ultimately enhancing cell division resulted in an increment in plant height, higher LAI and DMP of sesame crop (Raja et al., 2007). Besides, the application of boron increased growth parameters due to its contribution to cell wall formation and the deficient plants remain stunted at the same time boron supply reduces the lignifications. Hence, histologically, the plant cell continues to grow, especially at the tips with elongation of epicotyls and hypocotyls. Further, the results proved that positive interaction between $B$ and $S$ might synergistically enhance the dry matter and seed yields. These results were in line with the findings of Bahaa El-Din , 2015) for sunflower.

\section{Effect of $\mathrm{S}, \mathrm{Zn}$ and $\mathrm{B}$ on the yield components and yield of sunflower}

The yield determining components such as head diameter and the number of seeds per head were significantly increased with the treatment supplied through $\mathrm{S}$ $@ 40 \mathrm{~kg} \mathrm{ha}^{-1}$ as soil application and Zn @ $0.5 \%$ and B @ $0.3 \%$ as foliar spray during both the year of crop period (Table 1). Among the sulphur levels, $40 \mathrm{~kg}$ of $S$ recorded higher yield components viz., head diameter of 17.1 and $16.7 \mathrm{~cm}$, and a number of filled seeds per head of 924 and 895 during both the crop period. Besides, the cumulative effect of micronutrients such as $\mathrm{Zn}$ and $\mathrm{B}$, predominantly play an important role in the enhancement of yield components. This might be due to the positive interaction between inorganic $\mathrm{N}$ and $\mathrm{S}$ results in fulfilling the crop nutrient need in the quickest manner.

Besides, efficient crop architecture as brought by an increased leaf number and consequent LAl coupled with effective uptake of nutrients, especially adequate supply of $S$ might have resulted in the increased synthesis of photosynthates and produced a higher floret number of sunflower crop (Ravikumar et al., 2016). Furthermore, the cumulative effect of $\mathrm{Zn}$ and $\mathrm{B}$ and their positive interaction with $S$ and their unanimous role in the synthesis of IAA, metabolism of auxin and formation of chlorophyll synthesis) and predominant role of boron helps in increasing the yield of the crop. The lowest value of head diameter and number of seeds per head recorded in RDF alone supplied treatments. This might be due to the very meagre availability of secondary and micronutrients such as $\mathrm{Zn}$ and $\mathrm{B}$. Even though the soil has above critical $z n$ and $B$ levels, the soil may realise low mineralization of these elements might have reduced the availability and causes the deficiency of plants. Where the supply of these elements in other treatments may satisfy the crop requirements, the seed yield and stalk yield were increased with $\mathrm{S}$ at $40 \mathrm{~kg}$ as soil application + Zn @ 0.5\% + B $0.3 \%$ as foliar spray with the value of 2371 and 2127 $\mathrm{kg} \mathrm{ha}^{-1}$ and stalk yield of 3312 and $3142 \mathrm{~kg} \mathrm{ha}^{-1}$ during both the crop period. This could be ascribed due to a positive interaction of $\mathrm{S}$ and $\mathrm{B}$ with $\mathrm{N}$ and interaction themselves led to increased crop growth parameters. These enhanced growth attributes jointly contributed 
Table 1. Effect of $S$ and micronutrients $(\mathrm{Zn}$ and $\mathrm{B})$ on yield components and yield of sunflower.

\begin{tabular}{|c|c|c|c|c|c|c|c|c|}
\hline \multirow[b]{2}{*}{ Treatments } & \multicolumn{4}{|c|}{ Crop I } & \multicolumn{4}{|c|}{ Crop II } \\
\hline & $\begin{array}{l}\text { Head } \\
\text { Diameter } \\
\text { in } \mathrm{cm}\end{array}$ & $\begin{array}{l}\text { No of filled } \\
\text { seeds/ } \\
\text { Head }\end{array}$ & $\begin{array}{l}\text { Seed } \\
\text { yield } \\
\text { kg / ha }\end{array}$ & $\begin{array}{l}\text { Stalk } \\
\text { yield } \\
\text { kg / ha }\end{array}$ & $\begin{array}{l}\text { Head } \\
\text { Diameter } \\
\text { in } \mathrm{cm}\end{array}$ & $\begin{array}{l}\text { No of filled } \\
\text { seeds/ } \\
\text { Head }\end{array}$ & $\begin{array}{l}\text { Seed } \\
\text { yield } \\
\mathrm{kg} / \mathrm{ha}\end{array}$ & $\begin{array}{l}\text { Stalk yield } \\
\text { kg / ha }\end{array}$ \\
\hline $\begin{array}{l}\mathrm{T}_{1}-\mathrm{RDF} \text { alone as soil } \\
\text { application }\end{array}$ & 12.0 & 710 & 1791 & 2725 & 11.7 & 680 & 1665 & 2681 \\
\hline $\begin{array}{l}\mathrm{T}_{2^{-}} \mathrm{RDF}+\mathrm{S} @ 20 \mathrm{~kg} \\
\mathrm{ha}^{-1} \text { as soil application } \\
\mathrm{T}_{3}-\mathrm{RDF}+\mathrm{S} @ 20 \mathrm{~kg}\end{array}$ & 12.4 & 760 & 1854 & 2842 & 12.2 & 741 & 1701 & 2790 \\
\hline $\begin{array}{l}\text { ha }^{-1}+Z n @ 0.25 \% \text { as } \\
\text { foliar spray }\end{array}$ & 13.5 & 792 & 1946 & 2891 & 13.0 & 775 & 1769 & 2833 \\
\hline $\begin{array}{l}\mathrm{T}_{4}-\mathrm{RDF}+\mathrm{S} @ 20 \mathrm{~kg} \\
\mathrm{ha}^{-1}+\mathrm{B} @ 0.15 \% \text { as } \\
\text { foliar spray } \\
\mathrm{T}_{5^{-}} \mathrm{RDF}+\mathrm{S} @ 20 \mathrm{~kg}\end{array}$ & 13.9 & 824 & 1992 & 2922 & 13.5 & 801 & 1811 & 2876 \\
\hline $\begin{array}{l}\text { ha }^{-1}+\mathrm{Zn} @ 0.25 \% \text { and } \\
\text { B @ } 0.15 \% \text { as foliar } \\
\text { spray }\end{array}$ & 14.8 & 851 & 2112 & 2965 & 14.4 & 818 & 1881 & 2946 \\
\hline $\begin{array}{l}\mathrm{T}_{6}-\mathrm{RDF}+\mathrm{S} @ 40 \mathrm{~kg} \\
\mathrm{ha}^{-1} \text { as soil application }\end{array}$ & 15.1 & 865 & 2162 & 2998 & 14.8 & 830 & 1920 & 2980 \\
\hline $\begin{array}{l}\mathrm{T}_{7-} \mathrm{RDF}+\mathrm{S} @ 40 \mathrm{~kg} \\
\mathrm{ha}^{-1}+\mathrm{Zn} @ 0.5 \% \text { as } \\
\text { foliar spray } \\
\end{array}$ & 15.8 & 892 & 2241 & 3132 & 15.6 & 853 & 1991 & 3017 \\
\hline $\begin{array}{l}\text { ha }^{-1+} \mathrm{B} @ 0.3 \% \text { as } \\
\text { foliar spray }\end{array}$ & 16.2 & 902 & 2287 & 3175 & 15.9 & 868 & 2033 & 3051 \\
\hline $\begin{array}{l}\mathrm{T}_{9}-\mathrm{RDF}+\mathrm{S} @ 40 \mathrm{~kg} \\
\mathrm{ha}^{-1}+\mathrm{Zn} @ 0.5 \% \text { and B } \\
@ 0.3 \% \text { as foliar spray }\end{array}$ & 17.1 & 924 & 2371 & 3312 & 16.7 & 895 & 2127 & 3142 \\
\hline C.D $(P=0.05)$ & 0.67 & 17.3 & 60.4 & 55.9 & 0.60 & 16.6 & 56.6 & 50.5 \\
\hline
\end{tabular}
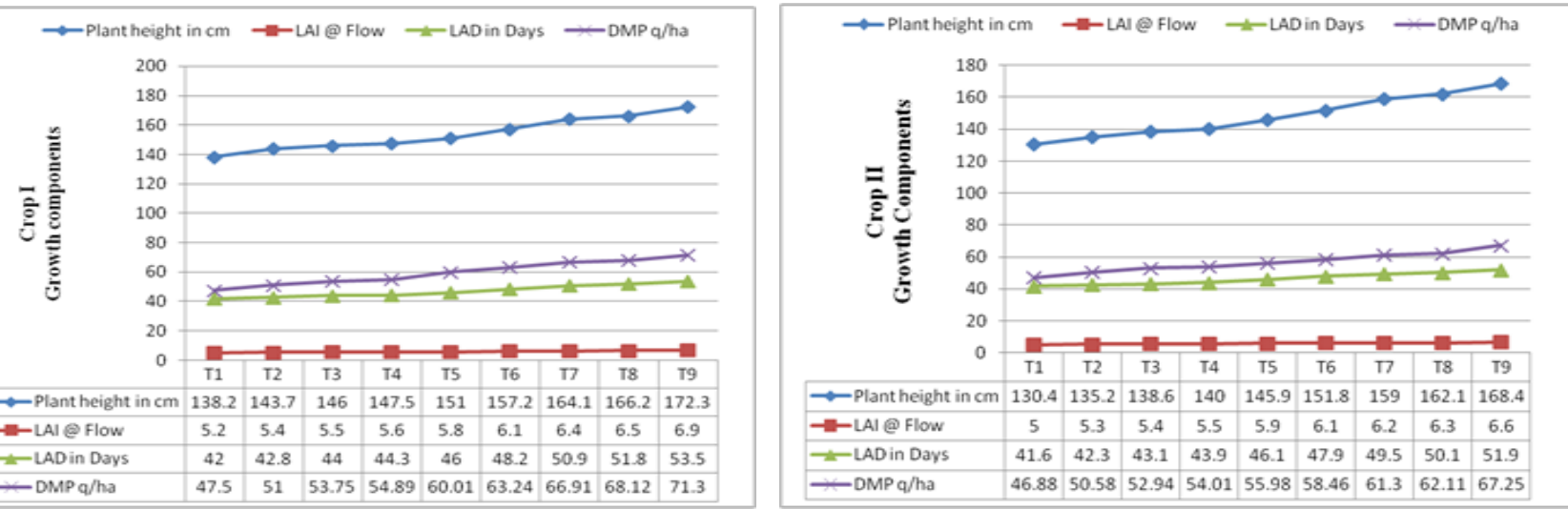

Fig.1. Effect of $S, Z n$ and $B$ on the growth components of hybrid sunflower.

and increased the yield potential (2371 and $2127 \mathrm{~kg}$ ha ${ }^{1}$ ) of the crop, as reflected by the higher seed yield. The reciprocation of overall improvement reflected in better source and sink relationship, tissue differentiation from somatic to reproductive and meristematic activity. The observed trend on seed yield and stalk yield in other treatments as follows $T_{8}=T_{7}>T_{6}=T_{5}>T_{4}=T_{3}>T_{2}>T_{1}$ during both the year of crop period. These results were concomitant with the findings of Oyinlola (2007) for sesame and (Abdul Aziz et al., 2016) for sunflower.

\section{Regression analysis}

The quadratic response regression analysis on the seed yield of sunflower predicted for the impact of the number of filled seeds per head and the results indicated that the increase in these parameters has positively influenced the seed yield of sunflower, which is indicated in the graph with the $R^{2}$ value and polynomial equation (Fig. 3 and 4). For instance, the polynomial equation and the results indicatedthat the increase in these parameters has significantly improved the yield of crop, which is reflected in the graph with the $R^{2}$ value and polynomial equation (Fig 3 and 4). For instance, polynomial equation $Y=0.0073 x 2-9.1672 x+4616.6$, with the $R^{2}$ value of 0.9958 was observed for the number of seed yield with seed yield during the first crop period. A 
Ravikumar, C. et al. / J. Appl. \& Nat. Sci. 13(1): 295 - 300 (2021)
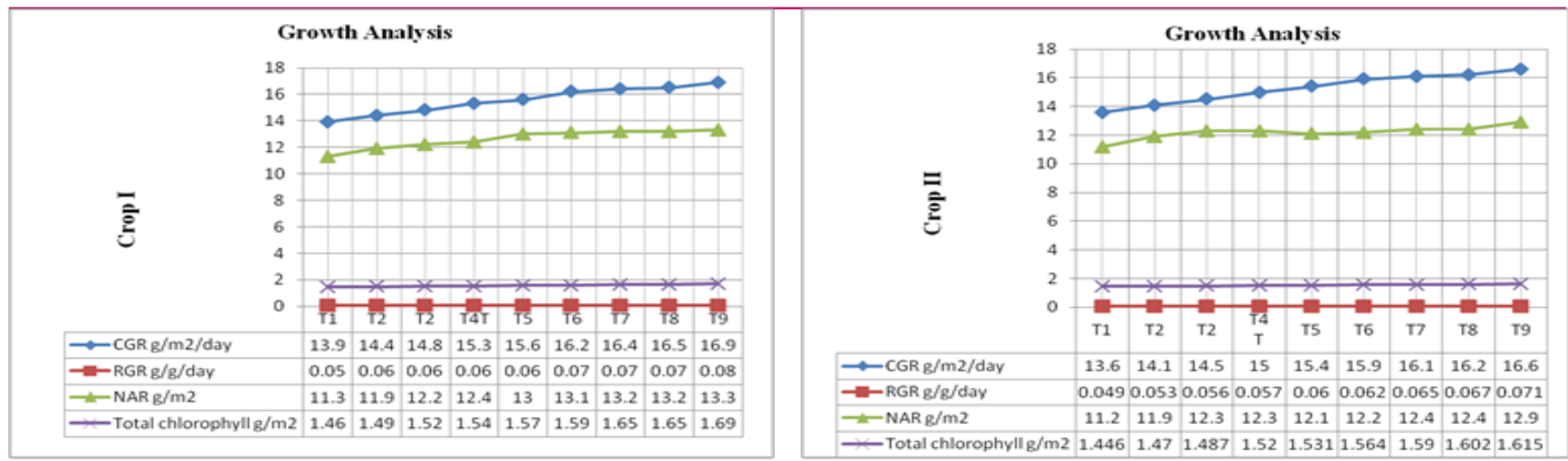

Fig. 2. Effect of $S, Z n$ and $B$ on the growth analysis of hybrid sunflower.
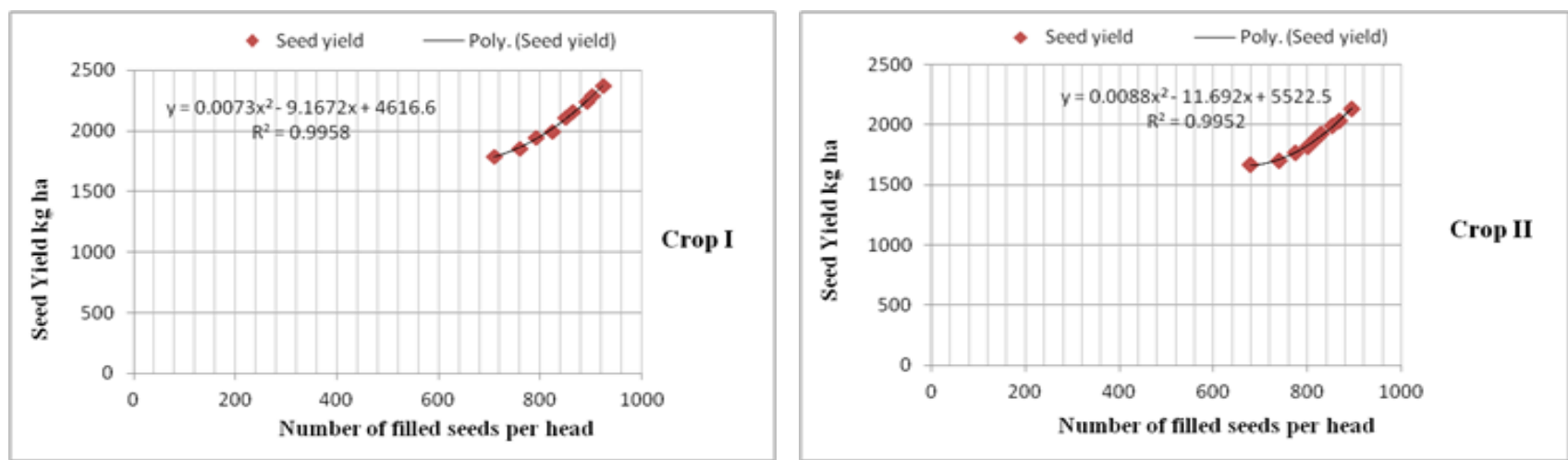

Fig. 3. Regression analysis of number of filled seeds vs seed yield.

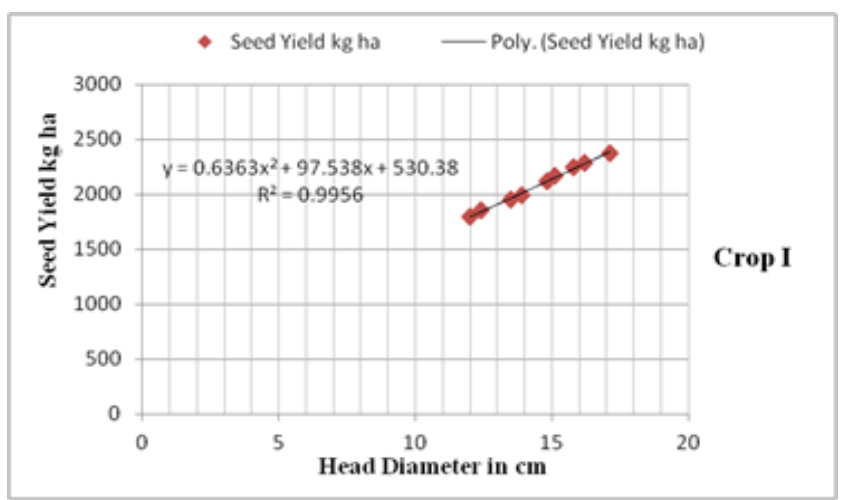

Fig. 4. Regression analysis of head diameter vs seed yield

similar trend was noticed in the head diameter (Fig 4). The final yield of the crop might be the cumulative effects of yield attributes that influence the complimentary parameters that could result in a positive relationship with higher productivity, which has been proved in the present study.

\section{Conclusion}

It may be concluded that application of S@ $40 \mathrm{~kg} \mathrm{ha}^{-1}$ basally as soil application along with RDF and micronutrients such as Zn @ $0.5 \%$ and B @ 0.3\% as foliar application at bud initiation, seed formation and ray floret formation stages enhanced all the growth, yield components and seed yield of hybrid sunflower (Helianthus annuus.L) compared to RDF alone. It

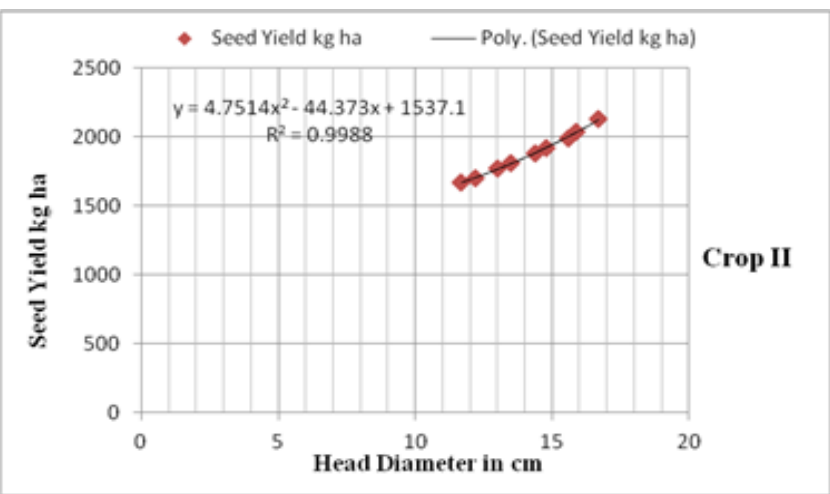

showed that B and S supply to sunflower crops at optimum levels are important for its productivity with all the recommended nutrients supplied.

\section{Conflict of interest}

The authors declare that they have no conflict of interest.

\section{REFERENCES}

1. Abdul Aziz Khan Bariach, Allah Wadhayo Gandhi, Shamsuddin Tunio and Qamaruddin Chachar ( 2016). Influence of micronutrients and their method of application on yield and yield components of sunflower. Pak. J. Bot.,48(5), 1925-1932.

2. Agele, S.O. (2003). Sunflower response to weather variations in rainy and dry cropping seasons in a tropical rain- 
forest zone. IJOB, 32, 17-33.

3. Arnon, D. I. (1949). Copper enzyme in isolated chloroplasts, polyphenol Beta vulagarisPI. Physiol.,24, 1-15.

4. Bahaa El-Din Mekki, (2015). Effect of boron foliar application on yield and quality of some sunflower (Helianthus annuus L.) cultivars. Journal of Agri. Sci. and Tech., B5: 309-316 Doi: 10.17265/2161-6264/2015.05.002.

5. FAO (2019). FAOSTAT, http://www.fao.org/faostat/en/ \#home.

6. GOI (2015). Guidelines for use of micronutrients, soil ameliorants and integrated nutrient management practices in National Food Security Mission (NFSM) states manual, Pp:7. Ministry of Agriculture, Govt. of India (GOI).

7. Gomez, A. A. and Gomez, R. A. 1976, Statistical procedure for Agricultural research with emphasis on rice. IRRI. Los Banos Philippines.

8. Hemantaranjan, A. (1996). Physiological and bio significance of Zinc in plants. Advancements in Micronutrient Research; Scientific publishers; Jodhpur, India. 151-178.

9. Marchner, H. (1995). Mineral nutrition of Higher Plants, $2^{\text {nd }}$ edn. Academic

10. Naser, A. Anjum ,Sarvajeet, S. Gill, Shahid Umar, Igbal Ahmed, Armando C. Duarte. And Eduarda Pereira (2012). Improving growth andproductivity of Oliferous brassica under changing environment: Significance of nitrogen and sulphur nutritiont and underlying mechanisms, The Scientific world Journal, 12. Doi:10.1100/2012/657808.

11. Neena, K. and Chitrlekha. C. (2001).Influence of variable Zinc on yield, oil content and physiology of sunflower. Commun. Soil Sci. Plant Analy., 32(19\&20): 3023-3030.

12. Neumann, P.M. (1982). Late season foliar fertrilization with macronutrients- Is there a theoretical base for increased seed yields. Journal of Plant Nutrition, 5, 1209-1215.

13. Oyinlola, E.Y. (2007). Effect of boron fertilizer on yield and oil content of three sunflower cultivars in the Nigerian savanna. J. Agron.6(3), 421-426. press, London, UK.

14. Raja A., Omar Hattab, K., Gurusawmy, L., Vembu, G., Suganya, K. S., (2007). Sulphur application on growth, yield and quality of sesame varieties. Int. J. Agric. Res., 2, 599-606.

15. Ravikumar, C., Ganapathy. M. and Vaiyapuri. V. (2016). Effect of sulphur fertilization on growth, yield and nutrient uptake of sunflower in north cauvery deltaic region, Int. J. Cur. Res. Rev., 8(22), 13-17.

16. Rego, Thomas.J., Sahrawat Kanwar.L., Wani Suhas.P. and Pardhasarthi Gazula. (2007). Widespread deficienceies of sulfur, boron, and zinc in Indian semi-arid tropical soils: on-farm crop responses. J. Plant Nutrition, 30, 156983.

17. Singh, M.V. and Goswami. V. (2014).Boron management in Indian agriculture. Ind. J. Fert., 10(5), 104-115.

18. Singh, M.V., Goswami. V. and Wanjari. R.H. (2019). Evaluation of right source of boron and sulphur for enhancing yield and quality of crops. Better crops- South Asia,11(1): 27-30.

19. Tandon, H. L. S. and Messick, D. L. (2002). Practical sulphur guide. The Sulphur Institute, Washington, D. C.

20. Vishnuvardhan Reddy, A., SudhakaraBabu, S.N., Radhakrishnan, T., Bhatia. V.S. and Rai. P.K. (2020). Status and technological options for increasing oilseeds production. National seminar on Technological innovations in oilseeds crops for enhancing productivity, profitability and nutritional security, ISOR, Hyderabad.

21. Wani, S.P., Sahrawat, K L, Sarvesh, K .V., Baburao, M. and Krishnappa, K. (2011). Soil fertility atlas for Karnataka, India, pp. 312. Manual International Crops Research Institute for the Semi-Arid Tropics, Pathencheru, Andhra Pradesh, India. 